\title{
Suicidal Ideation and Hopelessness among Mexican Adolescents Studying In Public and Private Schools: The Role of Family Factors
}

\author{
Dr. Alfredo Briones Aranda ${ }^{1}$, Prof. José Eduardo Suárez Santiago ${ }^{2}$, \\ Javier Ramírez Carballo ${ }^{3}$, Pascual Alonso Pérez Nango ${ }^{4}$, \\ Prof. Manuela Castellanos Pérez ${ }^{5}$, Dr. Víctor Manuel Vega Villa ${ }^{6}$
}

\section{ABSTRACT}

Background: The transition from childhood to adolescence is associated with suicidal ideation (SI) and feelings of hopelessness. The aim of this study was to investigate the prevalence of SI and hopelessness (and relevant family factors) among adolescents in southern Mexico studying in public and private high schools. Methods: A significant sample of high school students (15-19 years old) was taken in the city of Tuxtla Gutiérrez, the State of Chiapas, Mexico. The Beck scale for SI, the Beck hopelessness inventory, and a survey of family data were applied to adolescents, 364 in public and 240 in private high schools. Results: The teens in public schools showed a higher prevalence of hopelessness (32\%) and SI+hopelessness (10\%). In both public and private schools, these attitudes were more common among women as well as teens from small (3-4) families and those without a job. Conclusions: The behaviors found among teens of public and private high schools suggest the importance of a lack of family stability and economic solvency in the development of suicidal behavior. The present results may be useful in formulating strategies to prevent suicide.

Keywords: Suicidal Ideation, Hopelessness, Adolescents, Working Teens, Public Schools, Private Schools, Type of Family, Chiapas.

Suicide is a worldwide public health problem that leads to the death of approximately one million people each year (Ghasemi, Shaghaghi \& Allahverdipour, 2015). Between 2000 and

\footnotetext{
${ }^{1}$ Faculty of Human Medicine, Autonomous University of Chiapas (UNACH), Calle Central y 10a sur s/n, Tuxtla Gutiérrez, Chiapas, México

${ }^{2}$ School of Medicine, National Polytechnic Institute (IPN), México City

${ }^{3}$ Faculty of Human Medicine, UNACH, México

${ }^{4}$ Faculty of Human Medicine, UNACH, México

${ }^{5}$ Faculty of Human Medicine, UNACH, México

${ }^{6}$ Faculty of Human Medicine, UNACH, México

*Responding Author

(C) 2016 A Aranda, J Santiago, J Carballo, P Nango, M Pérez, V Villa; licensee IJIP. This is an Open Access Research distributed under the terms of the Creative Commons Attribution License (http://creativecommons.org/licenses/by/2.0), which permits unrestricted use, distribution, and reproduction in any Medium, provided the original work is properly cited.
} 


\section{Suicidal Ideation and Hopelessness among Mexican Adolescents Studying In Public and Private Schools: The Role of Family Factors}

2011 in Mexico, the official mortality rate due to suicide in children and adolescents doubled, going from 0.5 to 1.2 individuals per 100,000 inhabitants (Revuelta, Paredes, Rodríguez, Escondrillas \& Calderón, 2015). In developing countries, however, official statistics about suicidal behavior (SB) are not very reliable, meaning that the real number of suicides is probably even higher (Pérez, Rivera, Atienzo, Castro, Leyva \& Chavez, 2010).

The statistical category of SB comprises suicidal ideation (SI), a suicide attempt and a completed suicide (Rosales, Cordova \& Rosalba, 2012; Villalobos, 2010). SI refers to unusual thoughts focused on a desire and/or plan to commit suicide (Thakur, Gupta, Thakur, Mazta \& Sharma, 2015). It has been reported that up to $20 \%$ of the people suffering from SI attempt to commit suicide within one year (Borges, Orozco \& Medina, 2012).

On the other hand, hopelessness is a cognitive alteration in which the individual forms negative expectations about the future (Assari \& Lankarani, 2016; Beck, Weissman, Lester \& Trexler, 1974; Gooding et al., 2015; Huen, Ip, Ho \& Yip, 2015; Marco, Pérez \& García, 2016). A close relationship has been proposed between hopelessness and SI, since the former is influential in creating a risk of suicide (Antypa, Van der Does \& Penninx, 2010; Lamis, Ballard, May \& Dvorak, 2016).

The prevalence of SI dramatically increases during the transition from childhood to adolescence (Tsypes \& Gibb, 2016), and suicide attempts have been associated with the symptomology of a depressive state in adolescents (Carrazco \& del Barrio, 2007; Viñas, Jane \& Domenech, 2000). It is well known that SI can have a direct relation to diverse factors, especially the lack of harmony in the family dynamic (Donath, Graessel, Baier, Bleich \& Hillemacher, 2014; Lee, Park, Han, Kim, Chun \& Park, 2016; Thompson, Alonzo, Hu \& Hasin, 2016), problems in the school environment (Arango, Opperman, Gipson \& King, 2016; Thakur et al., 2015), sexual preference (Baiocco et al., 2014), and a low economic level (Song \& Lee, 2016; Thompson et al., 2016).

Accordingly, the family can exercise a counteracting balance on the SB of adolescents. Firstly, the family can facilitate a timely diagnosis of SB and at the right moment intervene to contribute to prevention (Granö, Karjalainen, Ranta, Lindgren, Roine \& Therman, 2016; Lee et al., 2016). Secondly, family dysfunction can form part of the adverse factors related to the risk of suicide in adolescents (Blandón, Carmona, Mendoza \& Medina, 2015).

The importance of studying SB lies not only in the life or death question, but also in the fact that adolescents who suffer from this condition undergo great psychological suffering and emotional drain (the latter for the individual and family), and can end up with a physical handicap (Borges, Orozco, Benjet \& Medina, 2010). Additionally, this problem has resulted in an economic cost to society in the range of billions of dollars (Klonsky, May \& Saffer, 2016). It is a shame that, in 


\section{Suicidal Ideation and Hopelessness among Mexican Adolescents Studying In Public and Private Schools: The Role of Family Factors}

spite of the increase in deaths by suicide in Mexican adolescents (Revuelta et al., 2015), the research in this field continues to be scarce, especially in the southern and southeastern region of the country.

Hence, the principal aim of the present study was to investigate, in adolescents from Chiapas studying in public or private high schools, the prevalence of feelings of hopelessness and SI, as well as some relevant family factors.

\section{METHODS}

\section{Study design and instruments}

This was a cross-sectional and retrospective study based on a questionnaire about family background and two inventories that explored SI and certain characteristics of a depressive state. The questionnaire had 7 questions, including age, gender, type of family, number of family members, and whether or not the teens worked. The Beck Scale for Suicide Ideation (BSSI) was used to quantify and evaluate the conscious recurrence to suicidal thoughts. It consists of 20 questions and is evaluated by giving a score, with a maximum of 40 points. This scale has been evaluated with Mexican adolescents, obtaining internal consistency indexes of $\alpha=0.84$ (González, Díaz, Ortiz, González \& González, 2000). The other inventory used, the Beck Hopelessness Inventory (BHI), also consists of 20 questions and has obtained a coefficient of internal consistency of $\alpha=0.93$ (Beck et al., 1974).

\section{Participants and sample selection}

Included in the study were adolescents between 15 and 19 years of age, males and females, who were high school students (in public or private schools) living in the city of Tuxtla Gutiérrez, in the State of Chiapas, Mexico. The registrar of the Secretary of Public Education (Secretaría de Educación Pública, or SEP) in Tuxtla Gutiérrez (SEP-CHIAPAS) was consulted, finding that a total of 30,180 students were enrolled in public schools and 8,515 in private schools. The sample was calculated based on an estimated error of $6 \%$ and a $94 \%$ level of confidence, resulting in a sample integrated by 364 students of public schools and 240 students of private schools. For the conformation of both samples, the city was divided into four quadrants: north, south, east and west. A private and public school were chosen at random in each quadrant. The number of students per selected school was determined by using a stratified sample. The study was carried out from July to December of 2015.

\section{Procedure}

After obtaining authorization from the school authorities, each of the three instruments was applied in the classroom of the school in question. Firstly, psychologists trained in the use of these instruments explained the motive of the survey to the participating students. Voluntary participation was requested, with a guarantee of absolute anonymity and confidentiality in the

(C) The International Journal of Indian Psychology, ISSN 2348-5396 (e) I ISSN: 2349-3429 (p) | 128 


\section{Suicidal Ideation and Hopelessness among Mexican Adolescents Studying In Public and Private}

Schools: The Role of Family Factors

management of information. Nobody refused to participate, and the process took approximately 30 minutes.

\section{Data analysis}

The data were first analyzed to determine simple frequency and percentages of the answers. Afterwards, the factors associated with SI and hopelessness were identified, and then two models of logistic regression were applied, obtaining odds ratios with a 95\% confidence interval (CI 95\%). The software used in all analysis was the Statistical Package for the Social Sciences (SPSS Statistics 20.0).

\section{RESULTS}

The prevalence of hopelessness was greater in the public schools (32\%), with predominance among women (19\%) compared to men (13\%). SI occupied second place (14\%), with the third place corresponding to a combination of both variables (10\%) (Table I).

Also in public schools, the percentage of SI was greater in the adolescents from two-parent families (10\%). For the teens with SI that belonged to single parent families, those with the mother as head of household more than doubled (3\%) the percentage of those with the father as the head (1\%). The pattern of the prevalence of hopelessness and the combination of SI and hopelessness was similar in regard to the type of family of the participating teens (Table 1).

Table I. Socioeconomic factors associated with suicidal ideation and hopelessness among adolescents in public schools.

\begin{tabular}{|c|c|c|c|c|c|c|c|c|c|c|}
\hline \multirow[t]{2}{*}{ Characteristics } & \multicolumn{2}{|c|}{$\begin{array}{l}\text { Without } \\
\text { suicidal } \\
\text { ideation \& } \\
\text { hopelessness }\end{array}$} & \multicolumn{2}{|c|}{$\begin{array}{l}\text { With suicidal } \\
\text { ideation }\end{array}$} & \multicolumn{2}{|c|}{$\begin{array}{l}\text { With } \\
\text { hopelessness }\end{array}$} & \multicolumn{2}{|c|}{$\begin{array}{l}\text { With suicidal } \\
\text { ideation \& } \\
\text { hopelessness }\end{array}$} & \multicolumn{2}{|c|}{ Total } \\
\hline & $n$ & $\%$ & $n$ & $\%$ & $n$ & $\%$ & $n$ & $\%$ & $n$ & $\%$ \\
\hline \multicolumn{11}{|l|}{ Gender } \\
\hline Women & 98 & 27 & 28 & 8 & 70 & 19 & 22 & 6 & 218 & 60 \\
\hline Men & 62 & 17 & 22 & 6 & 46 & 13 & 16 & 4 & 146 & 40 \\
\hline \multicolumn{11}{|l|}{ Type of family } \\
\hline $\begin{array}{l}\text { Two-parent } \\
\text { (father \& mother) }\end{array}$ & 111 & 30 & 35 & 10 & 80 & 22 & 30 & 8 & 256 & 70 \\
\hline Single-parent (father) & 3 & 1 & 4 & 1 & 4 & 1 & 0 & 0 & 11 & 3 \\
\hline $\begin{array}{l}\text { Single-parent } \\
\text { (mother) }\end{array}$ & 46 & 13 & 11 & 3 & 32 & 9 & 8 & 2 & 97 & 27 \\
\hline \multicolumn{11}{|l|}{ Family members } \\
\hline$>4$ & 34 & 9 & 6 & 2 & 4 & 1 & 8 & 2 & 52 & 14 \\
\hline $3-4$ & 126 & 35 & 44 & 12 & 11 & 31 & 30 & 8 & 312 & 86 \\
\hline \multicolumn{11}{|l|}{ Working } \\
\hline Yes & 28 & 8 & 6 & 2 & 34 & 9 & 9 & 2 & 77 & 21 \\
\hline No & 132 & 36 & 44 & 12 & 82 & 23 & 29 & 8 & 287 & 79 \\
\hline
\end{tabular}

(C) The International Journal of Indian Psychology, ISSN 2348-5396 (e) | ISSN: 2349-3429 (p) | 129 


\section{Suicidal Ideation and Hopelessness among Mexican Adolescents Studying In Public and Private Schools: The Role of Family Factors}

The adolescents in public schools that did not work or that belonged to small families (3 or 4 members) predominated considerably in each of the variables studied (SI, hopelessness, and SI + hopelessness; Table II).

Table II. Socioeconomic factors associated with suicidal ideation and hopelessness among adolescents in private schools.

\begin{tabular}{|c|c|c|c|c|c|c|c|c|c|c|}
\hline \multirow[t]{2}{*}{ Characteristics } & \multicolumn{2}{|c|}{$\begin{array}{l}\text { Without } \\
\text { suicidal } \\
\text { ideation \& } \\
\text { hopelessness }\end{array}$} & \multicolumn{2}{|c|}{$\begin{array}{l}\text { With } \\
\text { suicidal } \\
\text { ideation }\end{array}$} & \multicolumn{2}{|c|}{$\begin{array}{l}\text { With } \\
\text { hopelessness }\end{array}$} & \multicolumn{2}{|c|}{$\begin{array}{l}\text { With } \\
\text { suicidal } \\
\text { ideation \& } \\
\text { hopelessness }\end{array}$} & \multicolumn{2}{|c|}{ Total } \\
\hline & $n$ & $\%$ & $n$ & $\%$ & $n$ & $\%$ & $n$ & $\%$ & $n$ & $\%$ \\
\hline \multicolumn{11}{|l|}{ Gender } \\
\hline Women & 74 & 31 & 34 & 14 & 6 & 3 & 5 & 2 & 119 & 50 \\
\hline Men & 76 & 32 & 27 & 11 & 8 & 3 & 10 & 4 & 121 & 50 \\
\hline \multicolumn{11}{|l|}{ Type of family } \\
\hline Two-parent (father \& mother) & 116 & 48 & 42 & 18 & 9 & 4 & 8 & 3 & 175 & 73 \\
\hline $\begin{array}{l}\text { Single-parent } \\
\text { (father) }\end{array}$ & 5 & 2 & 4 & 2 & 1 & 0.5 & 1 & 0.5 & 11 & 5 \\
\hline $\begin{array}{l}\text { Single-parent } \\
\text { (mother) }\end{array}$ & 29 & 12 & 15 & 6 & 4 & 1 & 6 & 3 & 54 & 22 \\
\hline \multicolumn{11}{|l|}{ Family members } \\
\hline$>4$ & 56 & 23 & 9 & 4 & 3 & 1 & 3 & 1 & 71 & 29 \\
\hline $3-4$ & 94 & 40 & 52 & 21 & 11 & 5 & 12 & 5 & 169 & 71 \\
\hline \multicolumn{11}{|l|}{ Working } \\
\hline Yes & 24 & 10 & 8 & 3 & 3 & 1 & 3 & 1 & 38 & 15 \\
\hline No & 126 & 53 & 53 & 22 & 11 & 5 & 12 & 5 & 202 & 85 \\
\hline
\end{tabular}

In private schools the prevalence of SI represented the greatest proportion (25\%), with predominance among women (14\%) compared to men (11\%). Following a similar pattern was hopelessness $(6 \%)$ or the combination of hopelessness and SI $(6 \%)$. In the latter category, interestingly, men represented a greater percentage (4\%) compared to women (2\%) (Table II).

In the private schools, like in the public schools, the predominance of teens with SI (18\%) and hopelessness (4\%) lived in two-parent families. In regard to the combination of SI and hopelessness, curiously, there was a similar percentage of teens from two-parent families (3\%) and one-parent families with the mother in charge (3\%). Also like in public schools, most of the teens with suicide-related behavior (SI, hopelessness, SI + hopelessness) did not work and/or belonged to small families (3 or 4 members).

In the total population under study, a predominance of women versus men was observed with hopelessness (13\% vs. $9 \%)$ or SI (11\% vs. $8 \%)$. However, an equal percentage was found for each gender (4.5\%) in the SI + hopelessness category (Figure 1).

(c) The International Journal of Indian Psychology, ISSN 2348-5396 (e) | ISSN: 2349-3429 (p) | 130 


\section{Suicidal Ideation and Hopelessness among Mexican Adolescents Studying In Public and Private Schools: The Role of Family Factors}

Figure 1. Suicidal ideation and hopelessness according to gender.

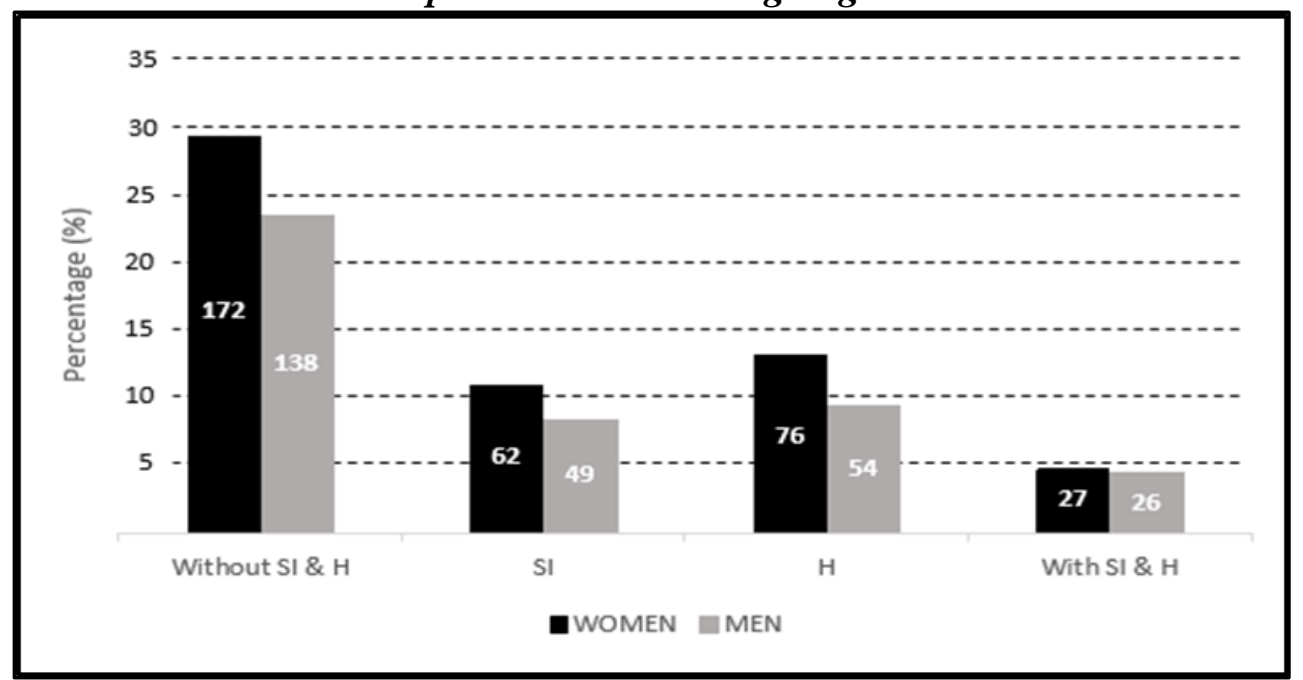

The bars represent the percentage of the total population under study. Without SI \& $\mathrm{H}=$ without suicidal ideation and hopelessness; $\mathrm{SI}=$ with suicidal ideation; $\mathrm{H}=$ with hopelessness; With SI \& $\mathrm{H}=$ with suicidal ideation and hopelessness.

Each of the behaviors were analyzed separately for the public and private schools (Figure 2), and compared with the total population under study. In private schools, SI occupied the first place among the three studied behaviors, followed by hopelessness and then SI + hopelessness. In public schools, on the other hand, hopelessness represented the greatest percentage, followed by SI and the combination. Although the percentage of the combination of SI and hopelessness represented the lowest percentage of the participating teens in both types of schools, it is noteworthy that the percentage in public schools (10\%) was almost double that of private schools (6\%). In the total population, hopelessness represented the greatest prevalence (22\%), followed by SI (18\%) and the combination of both behaviors (9\%) (Figure 2).

Figure 2. Comparison of suicidal ideation and hopelessness in adolescents of public and private schools, and in the total population under study.

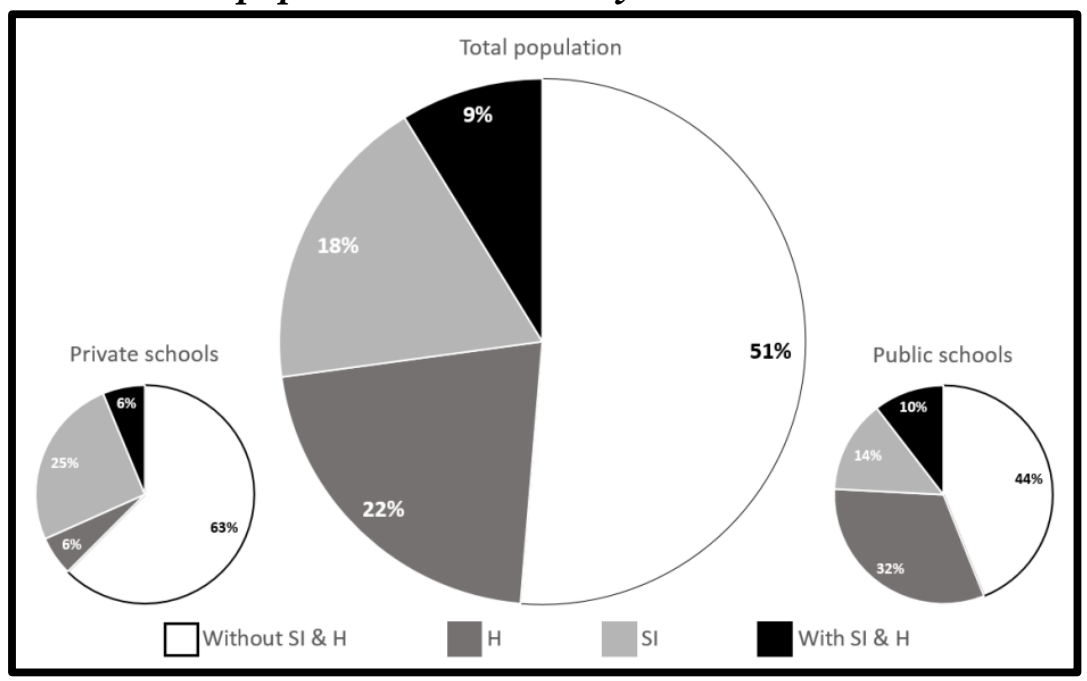

(C) The International Journal of Indian Psychology, ISSN 2348-5396 (e)| ISSN: 2349-3429 (p) | 131 
Without SI \& H = without suicidal ideation and hopelessness; SI = with suicidal ideation; $\mathrm{H}=$ with hopelessness; With SI \& H = with suicidal ideation and hopelessness.

In the public schools, hopelessness was significantly correlated with living in small families (OR $=2.78 ; \mathrm{p}<0.05)$ or not working $(\mathrm{OR}=2.0 ; \mathrm{p}<0.05)$ (Table IIIa). In private schools, the only significant correlation was between $\mathrm{SI}$ and belonging to a small family $(\mathrm{OR}=2.99 ; \mathrm{p}<0.05$, IC=95\%) (Table IIIb).

Table IIIa. Estimated risk of suicidal ideation and hopelessness for adolescents in public schools $(n=364)$. Results based on multinominal logistic regression with simultaneous adjustment for multiple variables.

\begin{tabular}{|c|c|c|c|c|c|c|c|c|}
\hline \multirow[t]{2}{*}{ Characteristics } & \multicolumn{4}{|c|}{ With suicidalideation } & \multicolumn{4}{|c|}{ With hopelessness } \\
\hline & $\mathbf{O R}^{1}$ & $\mathbf{E S}^{2}$ & $\mathbf{P}>\mathbf{Z}$ & IC $95 \%^{3}$ & OR & ES & $\mathbf{P}>\mathbf{z}$ & IC $95 \%$ \\
\hline \multicolumn{9}{|l|}{ Sex } \\
\hline Women & 1.00 & - & - & - & 1.00 & - & - & - \\
\hline Men & 0.84 & 0.24 & 0.499 & $0.52-1.37$ & 0.98 & 0.21 & 0.960 & $0.64-1.51$ \\
\hline \multicolumn{9}{|l|}{ Tipe of family } \\
\hline Twoparents (Fahter\&Mother) & 1.00 & - & - & - & 1.00 & - & - & - \\
\hline Single parent (Father) & 0.42 & 0.68 & 0.212 & $0.11-1.63$ & 1.31 & 0.63 & 0.665 & $0.37-4.61$ \\
\hline Single parent (Mother) & 1.39 & 0.29 & 0.254 & $0.78-2.48$ & 1.07 & 0.24 & 0.768 & $0.66-1.72$ \\
\hline \multicolumn{9}{|l|}{ Familymembers } \\
\hline$>4$ & 1.00 & - & - & - & 1.00 & - & - & - \\
\hline $3-4$ & 0.84 & 0.33 & 0.617 & $0.43-1.64$ & 2.78 & 0.34 & 0.003 & $1.40-5.50$ \\
\hline \multicolumn{9}{|l|}{ Working } \\
\hline Yes & 1.00 & - & - & - & 1.00 & - & - & - \\
\hline No & 0.70 & 0.31 & 0.2801 & $0.38-1.32$ & 2.00 & 0.25 & 0.007 & $1.20-3.33$ \\
\hline $\begin{array}{l}1 \text { Odds ratio } \\
2 \text { Standard error } \\
3 \text { Confidence interval }\end{array}$ & & & & & & & & \\
\hline
\end{tabular}

(c) The International Journal of Indian Psychology, ISSN 2348-5396 (e)| ISSN: 2349-3429 (p) | 132 
Suicidal Ideation and Hopelessness among Mexican Adolescents Studying In Public and Private Schools: The Role of Family Factors

Table IIIb. Estimated risk of suicidal ideation and hopelessness $(n=240)$ for adolescents in private schools. Results based on multinominal logistic regression with simultaneous adjustment for multiple variables.

\begin{tabular}{|c|c|c|c|c|c|c|c|c|}
\hline \multirow[t]{2}{*}{ Characteristics } & \multicolumn{4}{|c|}{ With suicidal ideation } & \multicolumn{4}{|c|}{ With hopelessness } \\
\hline & OR & ES & $\mathbf{P}>\mathbf{Z}$ & IC $95 \%$ & OR & ES & $\mathbf{P}>\mathbf{z}$ & IC $95 \%$ \\
\hline \multicolumn{9}{|l|}{ Sex } \\
\hline Women & 1.00 & - & - & - & 1.00 & - & - & - \\
\hline Men & 0.90 & 0.28 & 0.733 & $0.52-1.58$ & 0.58 & 0.40 & 0.184 & $0.26-1.29$ \\
\hline \multicolumn{9}{|l|}{ Type of family } \\
\hline Two-parent (father \& mother) & 1.00 & - & - & - & 1.00 & - & - & - \\
\hline Single-parent (father) & 0.62 & 0.32 & 0.153 & $0.33-1.18$ & 0.48 & 0.82 & 0.377 & $0.09-2.42$ \\
\hline Single-parent (mother) & 0.48 & 0.62 & 0.242 & $0.14-1.64$ & 0.47 & 0.43 & 0.084 & $0.20-1.10$ \\
\hline \multicolumn{9}{|l|}{ Family members } \\
\hline$>4$ & 1.00 & - & - & - & 1.00 & - & - & - \\
\hline $3-4$ & 2.99 & 0.35 & 0.001 & $1.49-5.99$ & 1.44 & 0.45 & 0.424 & $0.58-3.5$ \\
\hline \multicolumn{9}{|l|}{ Working } \\
\hline Yes & 1.00 & - & - & - & 1.00 & - & - & - \\
\hline No & 0.85 & 0.38 & 0.694 & $0.40-1.85$ & 1.53 & 0.49 & 0.391 & $0.57-4.07$ \\
\hline
\end{tabular}

\section{DISCUSSION}

Pérez et al. reported in 2010 that the prevalence of SI in Mexican teens ranged from 13 to 49\%, with predominance among women. Similar results have been found in this age group in distinct locations in Mexico. For example, SI was a behavior among $14.7 \%$ of teens in the State of Morelos (Rosales et al., 2012), 13\% in the State of Guanajuato and 41\% in the State of Chiapas (Pérez et al., 2010). The present study is in agreement with these reports, finding a prevalence of $27 \%$ of SI or SI + hopelessness for the teens of public and private schools, with a predominance among women.

In relation to women, in Chiapas there is an alarming presence of adverse socioeconomic factors such as poverty, teen pregnancy, and gender-based violence (González, Vega, Romero, Vega \& Cabrera, 2008; INEGI, 2015; Martínez, García, Trujillo \& Noriero, 2014). These conditions have been linked to the presence of SB in other contexts (González et al., 2003; Lee et al., 2016; Pérez, Uribe, Alexandra, Bahamón, Verdugo \& Ochoa, 2013; Song \& Lee, 2016; Thompson et al., 2016).

(c) The International Journal of Indian Psychology, ISSN 2348-5396 (e) | ISSN: 2349-3429 (p) | 133 


\section{Suicidal Ideation and Hopelessness among Mexican Adolescents Studying In Public and Private Schools: The Role of Family Factors}

On the other hand, the reported prevalence of depression among teens in Mexico ranges from 1017\% (Cubillas, Román, Abril \& Galaviz, 2012; Villatoro et al., 2011). This is in agreement with the prevalence of hopelessness in the present study (22\%), which is a symptom associated with depression that was observed in both types of schools.

The teens in public schools presented a much greater percentage of hopelessness compared to those in private schools, which coincides with a previous report in Mexico that explored depressive symptoms in similar situations (Moad, 2007), but differs from a study done in Argentina where the type of school apparently did not influence the prevalence of teen depression (Monterizino \& Benejam, 2006). This discrepancy may be explained by the sample size and the particular population under study, as well as by the psychometric instrument utilized in each case.

The predominance of SI and hopelessness among teens from single-parent families, both in the private and public schools of the current study, may have a relation to the increase in marital dissolution in Tuxtla Gutiérrez (Briones, Vega, López, Castellanos \& Suárez, 2014, Donath et al., 2014). This is in agreement with various studies that evidence a greater prevalence of SI in disintegrated or separated families in comparison to those with greater cohesion (Hedeland, Teilmann, Jørgensen \& Thiesen, 2016; Klonsky et al., 2016; Pérez et al., 2013; Sarmiento \& Aguilar, 2011).

In another context, the correlation found in the public high schools between adolescents who were not working and hopelessness is difficult to interpret, since lack of employment is predominant in this age group. However, it could possibly have a relation to what was reported in another study, that the condition of not working characterized young people who presented SB (Blandón et al., 2015). This suggests the possibility that having a job provides a positive influence on the security and economic independence of teens, which might result in a decrease in SB. Future studies are needed on this variable in order to explore these ideas.

Moreover, hopelessness has been proposed as a proximal risk factor of suicide in several theories (Assari \& Lankarani, 2016; Beck et al., 1974; Gooding et al., 2015; Huen et al., 2015; Marco et al., 2016), as representing a greater risk of suicide (Thakur et al., 2015; Viñas et al., 2000), and as a predictor of eventual suicide (Lamis et al., 2016), especially in adolescents. Hence, it should be alarming that there was a great prevalence of hopelessness in the public schools. It is possible that the aforementioned dysfunctionality of the family nucleus is implicated in the widespread existence of this feeling about the future.

With relation to the economic profile of Mexican families, a new classification and distribution has recently been proposed in which the lower class constitutes $60 \%$, the lower-middle class 


\section{Suicidal Ideation and Hopelessness among Mexican Adolescents Studying In Public and Private Schools: The Role of Family Factors}

$20 \%$, the upper-middle class $14 \%$, the lower-upper class $5 \%$, and the highest segment of the upper class $1 \%$ (DOF, 2014).

These statistics are in line with the percentages of teens that were enrolled nationally in public (82.3\%) or private high schools (17.7\%) in 2011 (Weiss, 2012). That is, it is likely that teens in public schools tend to come from the $80 \%$ of people in the lower and lower-middle class, and that the students in private high schools generally belong to the upper middle and upper classes. Consequently, it is plausible that the high percentage of hopelessness and SI + hopelessness for teens in public high schools holds a certain relation to the economic problems of the family. This idea is reinforced by the report that found a lack of money in the household as the main cause of drop outs in public high schools (49\%) (Martínez et al., 2012).

When comparing private and public high schools, there was a lower percentage of the combination of SI + hopelessness in the former (6\% versus 10\%). Nevertheless, this level in private schools is still worrisome, particularly due to the presence of some factors known to be involved in greater risk of suicide, such as the fact that the majority are men (González, Juárez, Montejo, Oseguera, Wagner \& Jiménez, 2015) and belong to a high socioeconomic class (Lee et al., 2016).

Finally, it is necessary to create preventative strategies to prevent suicide, taking into account the current results so that intervention by public and private agencies can target the most vulnerable groups.

\section{Acknowledgments}

The author appreciates all those who participated in the study and helped to facilitate the research process.

\section{Conflict of Interests}

The author declared no conflict of interests.

\section{REFERENCES}

Antypa, N., Van der Does, A.J., \& Penninx, B.W. (2010). Cognitive reactivity: Investigation of a potentially treatable marker of suicide risk in depression. Journal of Affective Disorders, $122,46-52$.

Arango, A., Opperman, K.J., Gipson, P.Y., \& King, C.A. (2016). Suicidal ideation and suicide attempts among youth who report bully victimization, bully perpetration and/or low social connectedness. Journal of Adolescence, 51, 19 - 29.

Asociación Americana de Psiquiatría. (2014). Manual diagnóstico y estadístico de los trastornos mentales (5ta ed.). VA: Arlington. 


\section{Suicidal Ideation and Hopelessness among Mexican Adolescents Studying In Public and Private Schools: The Role of Family Factors}

Assari, S., \& Lankarani, M.M. (2016). Depressive symptoms are associated with more hopelessness among white than black older adults. Public Health, 4, 82.

Baiocco, R., Ioverno, S., Cerutti, R., Santamaria, F., Fontanesi, L., Lingiardi, V., Baumgartnert, E., \& Laghi, F. (2014). Suicidal ideation in spanish and italian lesbian and gay young adults: the role of internalized sexual stigma. Psicothema, 26, 490 - 496.

Beck, A.T., Weissman, A., Lester, D., \& Trexler, L. (1974). The measurement of pessimism: The Hopelessness Scale. Journal of Consulting and Clinical Psychology, 42, 861 - 865.

Blandón, M.O., Carmona, J.A., Mendoza, M.Z., \& Medina, O.A. (2015). Suicidal ideation and associated in young university students from Medellin city. Archivo Médico de Camagüey, 19, $469-478$.

Borges, G., Orozco, R., Benjet, C., \& Medina, M.E. (2010). Suicide and suicidal behaviors in México: Retrospective and current status. Salud Pública de México, 52, 292 - 304.

Borges, G., Orozco, R., \& Medina, M.E. (2012). Risk index for attempted suicide in México. Salud Pública de México, 54, 595 - 606.

Briones, A., Vega, V., López, G., Castellanos, M., \& Suárez, J.E. (2014). Prevalencia de estrés en escolares de Tuxtla Gutiérrez, Chiapas, México y factores familiares asociados [Prevalence of stress among school children and associated family factors, in Tuxtla Gutiérrez, Chiapas, Mexico]. Información Psicológica, 108, 19 - 30.

Carrasco, M.A., \& del Barrio, M.V. (2007). Temperamental and personality variables in child and adolescent depressive symptomatology. Psicothema, 19, $43-8$.

Cubillas, M.J., Román, R., Abril, E., \& Galaviz, A.L. (2012). Depresión y comportamiento suicida en estudiantes de educación media superior en Sonora [Depression and suicidal behavior in senior high school students in Sonora]. Salud Mental, 35, 45 - 50.

DOF. (2014). Programa Nacional de Protección a los Derechos del Consumidor 2013 - 2018 en México [National Programfor Protection of Consumer Rights 2013 - 2018 in México]. Retrieved from http://dof.gob.mx/nota_detalle.php?codigo=5343849.

Donath, C., Graessel, E., Baier, D., Bleich, S., \& Hillemacher, T. (2014). Is parenting style a predictor of suicide attempts in a representative sample of adolescents? BMC Pediatrics, $14,1-13$.

Ghasemi, P., Shaghaghi, A., \& Allahverdipour, H. (2015). Measurement scales of suicidal ideation and attitudes: A systematic review article. Health Promotion Perspectives, 5, 156 $-168$.

Gooding, P., Tarrier, N., Dunn, G., Shaw, J., Awenat, Y., Ulph, F., \& Pratt, D. (2015). Effect of hopelessness on the links between psychiatric symptoms and suicidality in a vulnerable population at risk of suicide. Journal of Psychiatry Research, 230, 464 - 471.

González, C., Juárez, C.E., Montejo, L.A., Oseguera, G., Wagner, F.A., \& Jiménez, A. (2015). Ideación suicida y su asociación con drogas depresión e impulsividad de una muestra representativa de estudiantes de secundaria del estado de Campeche, México [Suicid alideation and it's association with drugs, depression and impulsivity in a high school

(c) The International Journal of Indian Psychology, ISSN 2348-5396 (e)| ISSN: 2349-3429 (p) | 136 


\section{Suicidal Ideation and Hopelessness among Mexican Adolescents Studying In Public and Private Schools: The Role of Family Factors}

student srepresentative simple fromthe State of Campeche, México]. Acta Universitaria. $25,29-34$.

González, S., Díaz, A., Ortiz, S., González, C., \& González, J.J. (2000). Características psicométricas de la escala de la ideación suicida de Beck (ISB) en estudiantes universitarios de la ciudad de México [Psychometric characteristics of the Beck scale for suicid alideation (BSSI) in university students of Mexico City]. Salud Mental, 23, 21 - 30.

González, G.J., Vega, M.G., Romero, S., Vega, A., \& Cabrera, C.E. (2008). A socio-spatial analysis of social exclusion and inequity in health in México. Salud Pública de Bogotá, 10, $15-28$.

Granö, N., Karjalainen, M., Ranta, K., Lindgren, M., Roine, M., \& Therman, S. (2016). Community-oriented family-based intervention superior to standard treatment in improving depression, hopelessness and functioning among adolescents with any psychosis-risk symptoms. Journal of Psychiatry Research, 237, 9 - 16.

Hedeland, R.L., Teilmann, G., Jørgensen, M.H., Thiesen, L.R., \& Andersen, J. (2016). Risk factors and characteristics of suicide attempts among 381 suicidal adolescents. In John Wiley \& Sons Ltd (Eds.), Nurturing The Child: Adolescent Suicide Attempts (pp. 1 - 8). Hillerød, Fundation Acta Pædiatrica.

Huen, J.M., Ip, B.Y., Ho, S.M., \& Yip, P.S. (2015). Hope and hopelessness: The role of hope in buffering the impact of hopelessness on suicidal ideation. Plos one, 10, $1-18$.

INEGI. (2015). Panorama de violencia contra las mujeres de Chiapas ENDIREH 2011 - 2014 [View of violence against in Chiapas ENDIREH 2011 - 2014] Retrieved from http://www.webcitation.org/6kojMm72B.

Klonsky, E.D., May, A.M., \& Saffer, B.Y. (2016). Suicide, Suicide attempts, and suicidal ideation. Journal of Clinical Psychology, 12, 307 - 330.

Lamis, D.A., Ballard, E.D., May, A.M., \& Dvorak, R.D. (2016). Depressive symptoms and suicidal ideation in college students: the mediating and moderating roles of hopelessness, alcohol problems, and social support. Journal of Clinical Psychology, 79, 919 - 932.

Lee, S.Y., Park, E.C., Han, K.T., Kim, S.J., Chun, S.Y., \& Park, S. (2016). The association of level of internet use with suicidal ideation and suicide attempts in south korean adolescents: a focus on family structure and house hold economic status. Journal of Psychiatry, 61, 243 - 251.

Marco, J.H., Pérez, S., \& Garcia, J. (2016). Meaning in life buffers: the association between risk factors for suicide and hopelessness in participants with mental disorders. Journal of Clinical Psychology, 72, 689 - 700.

Martínez, M.A., Verdugo, E., Cárdenas, A.N., Flores, I.A., Martínez, J.M., Murguía, M.I., Pérez, J.E., Pérez, E.E., Reyes, M., Sánchez, X., \& Herrera, G. (2012). Reporte de la Encuesta Nacional de Deserción en la Educación Media Superior [Report of the National Survey of Desertion in High School]. Retrieved from 


\section{Suicidal Ideation and Hopelessness among Mexican Adolescents Studying In Public and Private Schools: The Role of Family Factors}

http://www.sems.gob.mx/work/models/sems/Resource/10787/1/images/Anexo_6Reporte_d e_la_ENDEMS.pdf.

Moad, C. (2007). Depresión en adolescentes de escuelas públicas y privadas [Depression among adolescents in public and prívate schools]. Psicología Iberoamericana, 15, 6- 12.

Monterizino, J., \& Benejam, L. (2006). Prevalencia de depresión en adolescentes escolarizados de la localidad de la Cocha (Tucumán) [Prevalence of depression among adolescent students of the locality of the la Cocha (Tucumán)]. Revista de la Facultad de Medicina de la UNT, 7, 15 - 19.

Pérez, B., Rivera, L., Atienzo, E., Castro, F., Leyva, A., \& Chávez, R. (2010). Prevalencia y factores asociados a la ideación suicida en adolescentes de educación media superior de la República mexicana [Prevalence of suicidal behavior among Mexican students and associated factors]. Salud Pública de México, 52, 324 - 333.

Peréz, A., Uribe, J.I., Alexandra, M.J., Bahamón, M., Verdugo, J.C., \& Ochoa, S. (2013). Estilos parentales como predictores de ideación suicida en estudiantes adolescentes [Parenting styles as predictors of suicid alideation in adolescents]. Psicologíadesde el Caribe, 30, 551 -568 .

Revuelta, A., Paredes, J., Rodríguez, K., Escondrillas, C., \& Calderón, B. (2015). Panorama epidemiológico y estadística de la mortalidad en México 2011 [Epidemiological over view and statistics of mortality in México 2011]. Retrieved from

http://www.epidemiologia.salud.gob.mx/doctos/infoepid/publicaciones/mortalidad/PEEMo rtalidad_VE2011.pdf.

Rosales, J., Cordova, M., \& Rosalba, R. (2012). Ideación suicida en estudiantes mexicanos: un modelo de relación multiple con variables de identificación personal [Suicid alideation in Mexican students: a model of multiple relation with variables of personal identification]. Psicología y Salud, 22, 63 - 74.

Sarmiento, C., \& Aguilar, J. (2011). Predictores familiares y personales de la ideación suicida en adolescentes [Parental and personal predictors of suicidal ideation in adolescents]. Psicología y Salud, 21, 25 - 30.

Song, H.B., \& Lee, S.A. (2016). Socioeconomic and lifestyle factors as risks for suicidal behavior among korean adults. Journal of Affective Disorders, 197, 21 - 8.

Thakur, D., Gupta, A., Thakur, A., Mazta, S.R., \& Sharma, D. (2015). Prevalence and predictors of suicidal ideations among school going adolescents in a hilly state of India. India Psychiatry Journal, 24, 140 - 3.

Thompson, R.G., Alonzo, D., Hu, M.C., \& Hasin, D.S. (2016). The influences of parental divorce and maternal versus paternal alcohol abuse on off spring life time suicide attempt. Drug Alcohol Review, DOI: 10.1111/dar.12441.

Tsypes, A., \& Gibb, B.E. (2016). Cognitive vulnerabilities and development of suicidal thinking in children of depressed mothers: A longitudinal investigation. Journal of Psychiatry Research, 30, 99 - 104. 


\section{Suicidal Ideation and Hopelessness among Mexican Adolescents Studying In Public and Private Schools: The Role of Family Factors}

Villalobos, G. (2010). Validez y fiabilidad del inventario de ideación suicida positiva y negativa (PANSI), en estudiantes colombianos [Validity and reliability of the positive and negative suicid alideation inventory, in colombian students]. Psicología y Salud, 9, 509 - 520.

Villatoro, J.A., Gaytán, F., Moreno, M., Gutiérrez, M.L., Oliva, N., Bretón, M., López, M.A., Bustos, M., Medina, M.E., \& Blanco, C. (2011). Tendencias del uso de drogas en la ciudad de México: Encuesta de estudiantes 2009 [Trend in drug use in México city: student survey 2009]. Salud Mental, 34, 81 - 94.

Viñas, F., Jane, M., \& Domenech, E. (2000). Evaluación de la severidad de la ideación suicid aautoin for madaenescolares de 8 a 12 años [Assessment of self trepport suicidal ideation severity in 8 to 12 years old school children]. Psicothema, 12, $594-598$.

Weiss, E. (2012). Upper secondary education in Mexico to the challenge of universalization. Ciencias de la Educación, 6, 1 - 16.

How to cite this article: A Aranda, J Santiago, J Carballo, P Nango, M Pérez, V Villa (2016), Suicidal Ideation and Hopelessness among Mexican Adolescents Studying In Public and Private Schools: The Role of Family Factors, International Journal of Indian Psychology, Volume 4, Issue 1, No. 79, ISSN:2348-5396 (e), ISSN:2349-3429 (p), DIP:18.01.093/20160304, ISBN:978$1-365-56745-2$ 